\title{
ВПЛИВ РЕКРЕАЦІЙНОГО НАВАНТАЖЕННЯ НА МОРФОЛОГІЧНІ ОСОБЛИВОСТІ ЛІСОВОЇ ПІДСТИЛКИ (НПП «СКОЛІВСЬКІ БЕСКИДИ» УКРАЇНСЬКІ КАРПАТИ)
}

\author{
(C) Леневич O.I. \\ НПП «Сколівські Бескиди, м. Сколе \\ oksanalenevych@gmail.com \\ https://doi.org/10.34142/ 2708-583X.2019.21.08
}

\begin{abstract}
В статті проаналізовано морфологічні особливості структури лісової підстилки на еколого-пізнавальних та туристичному маршрутах в гірському регіоні. За результатами досліджень виявлено зміну основних параметрів лісової підстилки внаслідок витоптування. Встановлено, щчо на стежках шириною від 0.5 до 2 м

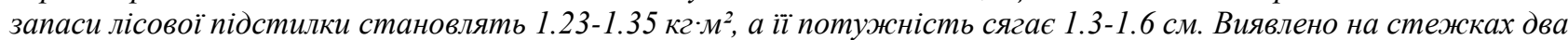
підгоризонти $L, F+H$. Із поступленням свіжого опаду на стежках можна виділити L, F та Н підгоризонти. На стежках шириною від 2 до 3 м запаси лісової підстилки становили 0.51-0.91 кг: ${ }^{2}$, що майже у двічі менше ніж на стежках з меншою шириною. Потужність підстилки на стежках шириною більше 2 м становлять 0.3-0.5 cм, з яких 0.2-0.4 становить F+H підгоризонт. На стежках крутизною схилу $\geq 15^{\circ}$ запаси та потужність лісової підстилки в пониженій частині стежки є приблизно на $10 \%$ більшими ніж у верхній ї̈ частині.

В основному, перерозподіл лісової підстилки спостерігається в межах стежки та її узбіччя. Зменшення запасів лісової підстилки на стежці зумовлено тим, щзо пошкоджена підстилка виноситься за межі стежки. У весняно-літній період року лісова підстилка змивається дощовими і талими водами формуючи на ї̈ узбіччі так звані «валики». Потужність та запаси лісової підстилки на узбіччі стежки суттєво залежать від ширини та напрямку стежки. Чим вужча стежка тим більші запаси підстилки і навпаки, чим ширша стежка тим менші фіксуються запаси лісової підстилки в межах узбіччя стежки. Потужність підстилки на узбіччях стежки

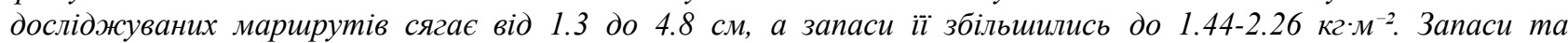
потужність лісової підстилки залежать від складу деревних порід, зімкнутості деревного ярусу, рельєфу місиевості.

Оиінено вплив рекреаційного навантаження на трунтовий покрив. Встановлено, щчо на початкових I-II стадіях (категоріях) рекреачійної дегресії лісова підстилка ущільнюється та подрібнюється формуючи потужний $F+H$ підгоризонт $i$ вкриває поверхню стежки. 3 посиленням рекреаційного навантаження (III стадія/категорія) запаси підстилки у ялиново-буково-ялицевому лісі в теплий період року становить менше 1 $\kappa 2: M^{2}$.
\end{abstract}

Ключові слова: лісова підстилка, потужність $і$ запаси, еколого-пізнавальний маршрут, НПП «Сколівські Бескиди», Украӥнські Карпати

Вплив рекреаційного навантаження на лісові екосистеми, їхню структуру та функціонування $\epsilon$ одним із деструктивних чинників, що неминуче призводять до істотних, а часом і до незворотних змін у природних екосистемах [8; 10]. 3 огляду на численні наукові праці, відзначається, що лісова підстилка $\epsilon$ найбільш вразливим компонентом до витоптування, а тому найбільше піддається рекреаційному впливу. Неодноразово в статтях відзна- чалось, що за відсутності лісової підстилки сильно ущільнюється верхній гумусовий горизонт [6;7], змінюється його водний та повітряний режим і як результат виникають ерозійні процеси $[3 ; 4 ; 10]$, що в сумарному негативно позначається на стійкості та функціонуванні лісових екосистем.

В більшості публікацій, автори висвітлюють негативний вплив туриста-рекреанта на екосистему, а ступінь пошкодженої території 
відносять до певної стадії (категорії) рекреаційної дегресії $[10,11]$. Однак значно менше уваги приділяється вивченню впливу рельєфу (мезо- i мікрорельєфу), як одного з факторів, що підсилює рекреаційний вплив та відмічається тільки в поодиноких комплексних наукових працях $[1 ; 6$; 7]. Тому актуальність даної теми зумовлена необхідністю вивчення закономірностей рекреаційного впливу на лісову підстилку з урахуванням всіх існуючих факторів.

\section{МАТЕРІАЛИ ТА МЕТОДИ}

В період з 2012-2014 років було досліджено 5 маршрутів в межах національного природного парку «Сколівські Бескиди» (надалі Парк). В даній статті для аналізу та обговорення, як модельні об'єкти, нами були вибрані два промаркованих маршрути - «СколеПарашка» та «Майдан-Парашка» та один немаркований, який потенційно може використовуватись населенням, що проживає в зоні діяльності Парку - «Коростів-Парашка». Вибрані дослідні ділянки мають відносно близькі кліматичні, геологічні умови, тип грунтів (по класифікації ФАО Dystric Cambisols) та рослинний покрив (ялиця біла Abies alba Mill., бук лісовий Fagus sylvatica L. і ялина європейська Picea abies (L.) Karst.). Однак, дані ділянки характеризуються різним ступенем складності проходження, транспортною доступністю до об'єктів рекреації, розвитком туристичної інфраструктури та тривалістю експлуатації.

Еколого-пізнавальний маршрут «Сколе-Парашка» розташований в на схилі південно-східної експозиції крутизною 9-15 в межах висот 600750 м н.р.м. Склад деревостану 5Яц3Бк2Ял, вік 60-80 років, зімкнутість крон - 0.7-0.9. Протяжність маршруту 10 км. Ширина стежки коливається в межах 1.852.20 м. На окремих ділянках стежки маршруту крутизною схилу $>20^{\circ}$ простежуються прояви водної ерозії. На цих ділянках лісова підстилка практично відсутня, а поверхня грунту візуально ущільнена.

Еколого-пізнавальний маршрут «Майдан-Парашка» проходить хребтом Середній, що локалізується в межах висот 800-860 м н.р.м., крутизна схилу - 5-10 . Склад деревостану - 8Бк2Ял віком до 80-ти років, зімкнутість крон - 0.7-0.8. Ширина стежки становить 0.65 1.50 м. Підстилка на маршруті пошкоджена та подрібнена, однак вкриває стежку. Поверхня грунту візуально не пошкоджена.

Туристичний маршрут «Коростів-Парашка» розташований в межах висот 790-860 м н.p.м., на схилі південної експозиції крутизною $10-20^{\circ}$ i нахилом поверхні стежки на 5-9 ${ }^{\circ}$. Склад деревостану 4Ял4Бк2Яц, вік близько 55-70 років, зімкнутість крон - 0.7-0.9. Ширина стежки 0.90-1.80 м. На окремих ділянках маршруту 3 крутизною понад $15^{\circ}$ спостерігаються прояви водної ерозії, поверхня стежки щебениста.

Дослідження були проведені в польових та лабораторних умовах за основними параметрами лісової підстилки. В межах лісового масиву зразки підстилки відбирали на основній стежці (ділянки №№ 1 і 2, які відповідно, приурочені до 
нижньої та верхньої частини маршруту (рис. 1). Відібрані зразки підстилки у різних частинах стежки (верхня та нижня) дають можливість адекватно оцінити вплив рекреаційного навантаження. Окрім цього, 3 метою оцінки масштабів впливу рекреації були відібрані зразки на узбіччі основної стежки на відстані 0.25 - 0.35 м від ділянок №№ 1 і 2 відповідно 1a і 2а. Контроль - лісова ділянка на відстані 50-100 м від стежки без видимого візуального рекреаційного впливу.

Вивчення морфологічних особливостей лісової підстилки проводили за Л.О. Карпачевским [5]. Використовували шаблон розміром
$0.25 \times 0.25$ м лісову підстилку відбирали в 5-кратній повторності. В польових умовах лінійкою вимірювали потужність лісової підстилки. Водночас здійснювались заміри потужності лісової підстилки за горизонтами L (опадовий), F (ферментативний) та $\mathrm{H}$ (гуміфікований). В лабораторних умовах відібрані зразки підстилки висушували до повітряно-сухого стану та зважували. Отримані дані усереднювали $\mathrm{i}$ перераховували на кг· $\mathrm{M}^{-2}$. Статистичне оцінювання результатів проводили 3 використанням електронних таблиць Office Excel та програмного пакету Statistica 6.0.

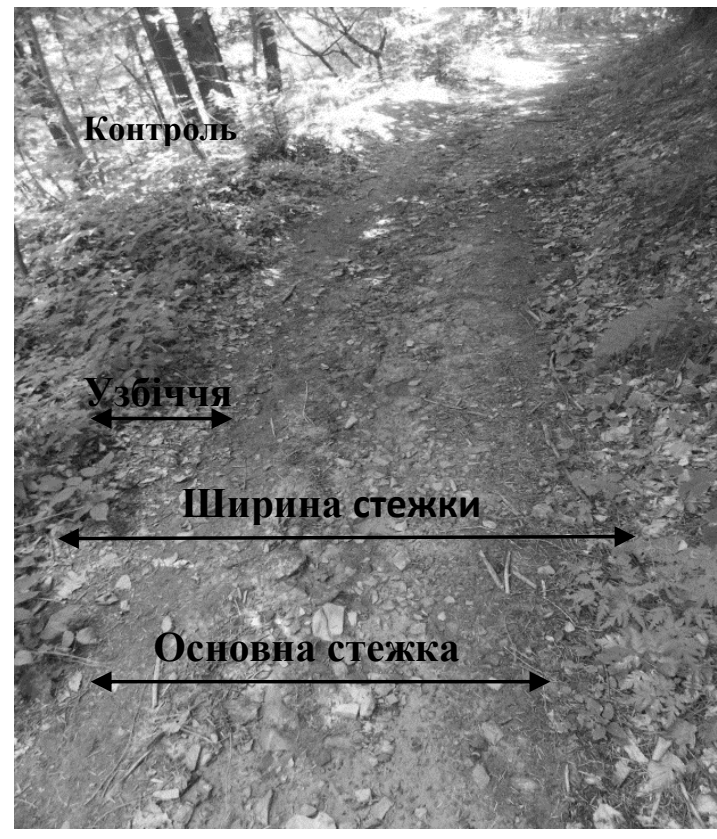

A

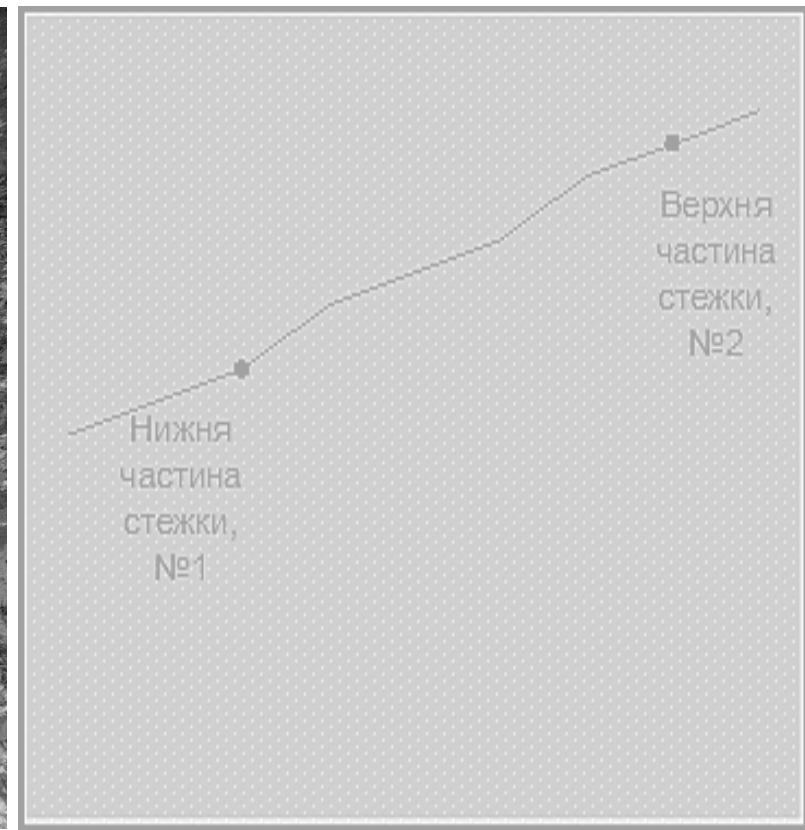

$\mathrm{B}$

Puc. 1 Дослідження еколого-пізнавальногомаршруту в гірському регіоні: відбір зразків лісової підстилки на стежці (А), відбір зразків на еколого-пізнавальному маршруті (B).

\section{РЕЗУЛЬТАТИ}

За результатами проведених досліджень встановлено, що запаси лісової підстилки в ялиново-буковоялицевому лісі у теплий період року становить $1.30-2.13 \quad \kappa \Gamma^{\cdot} \cdot \mathrm{M}^{-2}$. Їх потужність коливається від 2.10 до $4.0 \mathrm{~cm}$, а співвідношення горизонтів $(\mathrm{L}, \quad \mathrm{F}$ та $\mathrm{H}$ ) відповідає середнім показникам для підстилок зональних 
лісових екосистем Сколівських Бескидів (Українські Карпати) [9]. Досить добре простежується потужність підгоризонту L, a потужність $\mathrm{F}$ та $\mathrm{H}$ не завжди $\epsilon$ виразним.

За результатами проведених досліджень встановлено, що запаси лісової підстилки на стежках еколого-пізнавального маршруту «Сколе-Парашка» становлять менше 1 кг $\mathrm{M}^{-2}$ та $\epsilon$ значно меншими, ніж на контролі (табл.1). Внаслідок витоптування лісова підстилка сильно ущільнюється та подрібнюється на стежці. Ї̈̈ потужність $є$ незначною і становить 0.3-0.5 см проти 2.1 см у контролі. Потужність підстилки в основному формують підгоризонти $\mathrm{F}$ та Н, які практично не виділяються морфологічно. Якщо на стежках спостерігається тенденція до зменшення запасів підстилки, то в межах узбіч, навпаки, виявлено іiі нагромадження. Такий розподіл підстилки на стежках та їх узбіччях може бути зумовлений змиванням дрібних пошкоджених фракцій лісової підстилки із верхньої частини стежки, що приурочена до ділянки 3 крутизною схилу $\geq 15^{\circ}$. В результаті чого на всіх стежках формуються так звані «валики», потужність яких в значній мірі визначається шириною стежки, інтенсивністю рекреаційного навантаження та рельєфом місцевості [7]. Потужність підстилки на узбіччях стежки досліджуваного маршруту сягає $2.5 \mathrm{~cm}$, а запаси іiі збільшились до $1.65 \kappa^{\cdot} \cdot \mathrm{M}^{-2}$, що приблизно на $10 \%$ більше ніж у верхній частині узбіччя стежки (№2a). Потужність підстилки в межах узбіч збільшилась за рахунок підгоризонтів L та F, які формуються свіжовідкинутим листям зі стежки і напіврозкладеними гілками та плодами дерев.

Таблиия 1

Морфологічні особливості лісової підстилки на еколого-пізнавальних та туристичному маршрутах НПП Сколівські Бескиди (Українські Карпати)

\begin{tabular}{|c|c|c|c|c|c|c|c|c|c|c|}
\hline \multirow{3}{*}{$\begin{array}{l}E \\
E\end{array}$} & \multirow{3}{*}{$\begin{array}{l}\text { Місце } \\
\text { відбор } \\
\text { у } \\
\text { зразків }\end{array}$} & \multicolumn{3}{|c|}{$\begin{array}{c}\text { Еколого-пізнавальний } \\
\text { маршрут «Сколе- } \\
\text { Парашка» }\end{array}$} & \multicolumn{3}{|c|}{$\begin{array}{c}\text { Еколого-пізнавальний } \\
\text { маршрут «Майдан- } \\
\text { Парашка» }\end{array}$} & \multicolumn{3}{|c|}{$\begin{array}{l}\text { Туристичний маршрут } \\
\text { «Коростів-Парашка» }\end{array}$} \\
\hline & & $\begin{array}{l}\text { Запаси } \\
\text { підстилк } \\
\text { и }\end{array}$ & 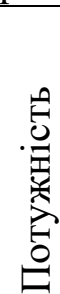 & $\begin{array}{l}\text { Потужніс } \\
\text { ть } \\
\text { підстилки } \\
\text { за } \\
\text { горизонта } \\
\text {-ми }\end{array}$ & $\begin{array}{l}\text { Запаси } \\
\text { підстил } \\
\text { ки }\end{array}$ & 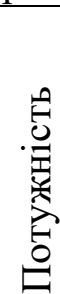 & $\begin{array}{l}\text { Потужніс } \\
\text { ть } \\
\text { підстилки } \\
\text { за гори- } \\
\text { зонтами }\end{array}$ & $\begin{array}{l}\text { Запаси } \\
\text { підстилк } \\
\text { и }\end{array}$ & 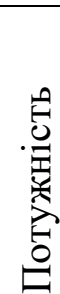 & $\begin{array}{l}\text { Потужніс } \\
\text { ть } \\
\text { підстилки } \\
\text { за } \\
\text { горизонта } \\
\text { ми }\end{array}$ \\
\hline & & $\kappa \Gamma^{\cdot} \mathrm{M}^{-2}$ & & $\mathrm{cM}$ & $\kappa \Gamma^{\cdot} \mathrm{M}^{-2}$ & & $\mathrm{~cm}$ & $\kappa \Gamma^{\cdot} \mathrm{M}^{-2}$ & & $\mathrm{CM}$ \\
\hline \multicolumn{11}{|c|}{ Стежка } \\
\hline 1 & $\begin{array}{l}\text { Нижня } \\
\text { частин } \\
\text { a, №1 }\end{array}$ & $\begin{array}{l}0.91 \pm 0.1 \\
9\end{array}$ & $\begin{array}{l}n \\
\text { on } \\
\text { Hn } \\
\text { on } \\
\text { wn }\end{array}$ & $\begin{array}{l}\mathrm{L}-0.1 \pm 0.2 \\
\mathrm{~F}+\mathrm{H}- \\
0.4 \pm 0.1\end{array}$ & $\begin{array}{l}1.35 \pm 0.2 \\
9\end{array}$ & 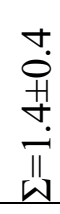 & $\begin{array}{l}\mathrm{L}-0.5 \pm 0.2 \\
\mathrm{~F}+\mathrm{H}- \\
0.9 \pm 0.4\end{array}$ & $\begin{array}{l}1.29 \pm 0.3 \\
0\end{array}$ & 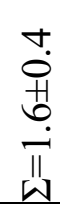 & $\begin{array}{l}\mathrm{L}-0.4 \pm 0.2 \\
\mathrm{~F}+\mathrm{H}- \\
1.2 \pm 0.3\end{array}$ \\
\hline 2 & $\begin{array}{l}\text { Верхня } \\
\text { частин } \\
\text { a, №2 }\end{array}$ & $\begin{array}{l}0.51 \pm 0.1 \\
2\end{array}$ & $\begin{array}{l}n \\
\text { ? } \\
\text { +1 } \\
\text { ? } \\
\text { II } \\
\text { W }\end{array}$ & $\begin{array}{l}\mathrm{L}-0.1 \pm 0.1 \\
\mathrm{~F}+\mathrm{H}- \\
0.2 \pm 0.1\end{array}$ & $\begin{array}{l}1.30 \pm 0.3 \\
2\end{array}$ & 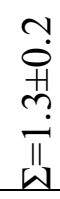 & $\begin{array}{l}\mathrm{L}-0.3 \pm 0.3 \\
\mathrm{~F}+\mathrm{H}- \\
1.0 \pm 0.7\end{array}$ & $\begin{array}{l}1.23 \pm 0.2 \\
5\end{array}$ & 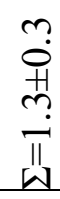 & $\begin{array}{l}\mathrm{L}-0.4 \pm 0.2 \\
\mathrm{~F}+\mathrm{H}- \\
0.9 \pm 0.2\end{array}$ \\
\hline
\end{tabular}




\begin{tabular}{|c|c|c|c|c|c|c|c|c|c|c|}
\hline \multicolumn{11}{|c|}{ Узбіччя стежки } \\
\hline 3 & $\begin{array}{l}\text { Нижня } \\
\text { частин } \\
\text { a, №1a }\end{array}$ & $\begin{array}{l}1.65 \pm 0.3 \\
5\end{array}$ & $\begin{array}{l}+ \\
0 \\
+1 \\
n \\
\pi \\
\pi\end{array}$ & $\begin{array}{l}\mathrm{L}-1.5 \pm 0.5 \\
\mathrm{~F}+\mathrm{H}- \\
2.0 \pm 0.4\end{array}$ & $\begin{array}{l}2.19 \pm 0.4 \\
9\end{array}$ & $\begin{array}{l}0 \\
\dot{\pi} \\
\infty \\
\dot{+} \\
\| \\
\omega\end{array}$ & $\begin{array}{l}\text { L-2.0 } \pm 0.9 \\
\text { F- } 1.7 \pm 0.5 \\
H-1.1 \pm 0.2\end{array}$ & $\begin{array}{l}2.23 \pm 0.7 \\
9\end{array}$ & 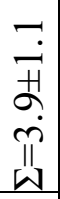 & $\begin{array}{l}\mathrm{L}-1.5 \pm 0.7 \\
\mathrm{~F}+\mathrm{H}- \\
2.4 \pm 0.5\end{array}$ \\
\hline 4 & $\begin{array}{l}\text { Верхня } \\
\text { частин } \\
\text { a, №2a }\end{array}$ & $\begin{array}{l}1.44 \pm 0.3 \\
8\end{array}$ & $\begin{array}{l}\dot{0} \\
+ \\
m \\
\dddot{\pi} \\
\text { W }\end{array}$ & $\begin{array}{l}\mathrm{L}-0.7 \pm 0.2 \\
\mathrm{~F}+\mathrm{H}- \\
1.2 \pm 0.4\end{array}$ & $\begin{array}{l}2.26 \pm 0.5 \\
9\end{array}$ & $\begin{array}{c}\dot{0} \\
+ \\
n \\
\dot{H} \\
\omega\end{array}$ & $\begin{array}{l}\text { L- } 2.1 \pm 1.1 \\
\text { F- } 1.4 \pm 0.4 \\
\text { H- } 1.0 \pm 0.2\end{array}$ & $\begin{array}{l}2.13 \pm 0.5 \\
8\end{array}$ & $\begin{array}{l}\dot{\vec{H}} \\
\dot{0} \\
\dot{\omega} \\
\omega\end{array}$ & $\begin{array}{l}\mathrm{L}-1.5 \pm 0.8 \\
\mathrm{~F}+\mathrm{H}- \\
2.1 \pm 0.5\end{array}$ \\
\hline \multicolumn{11}{|c|}{ Контроль } \\
\hline 5 & $\begin{array}{l}\text { Ялинов } \\
\text { о- } \\
\text { буково } \\
\text {-ялице- } \\
\text { вий ліс }\end{array}$ & $\begin{array}{l}1.53 \pm 0.2 \\
8\end{array}$ & $\begin{array}{l}\stackrel{+}{0} \\
\stackrel{+}{+} \\
\stackrel{i}{\pi} \\
\omega \\
\omega\end{array}$ & $\begin{array}{l}\mathrm{L}-1.0 \pm 0.3 \\
\mathrm{~F}+\mathrm{H}- \\
1.6 \pm 0.2\end{array}$ & $\begin{array}{l}2.13 \pm 0.3 \\
8\end{array}$ & 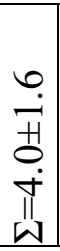 & $\begin{array}{l}\text { L- } 2.1 \pm 0.5 \\
\text { F- } 1.1 \pm 0.3 \\
H-0.8 \pm 0.2\end{array}$ & $\begin{array}{l}1.90 \pm 0.2 \\
1\end{array}$ & $\begin{array}{l}\tilde{o} \\
+1 \\
n \\
\tilde{H} \\
\omega\end{array}$ & $\begin{array}{l}\mathrm{L}-2.3 \pm 1.2 \\
\mathrm{~F}+\mathrm{H}- \\
1.2 \pm 0.4\end{array}$ \\
\hline
\end{tabular}

При дослідженні маршруту також було виявлено, що зі зростанням ширини стежки ( $\geq 2$ м) основні параметри лісової підстилки змінюються. Зокрема зменшуються запаси та потужність лісової підстилки, погано діагностуються підгоризонти (узбіччя стежки, №2a). На нашу думку, такі зміни в морфологічній будові підстилки зумовлені рекреаційним навантаженням та кращим доступом світла через прогалини [2], які в певній мірі залежать від ширини стежки.

Запаси лісової підстилки на еколого-пізнавальному маршруті «Майдан-Парашка» в осінній період року становили 2.13 кг· $\mathrm{M}^{-2}$. Запаси та потужність підстилки зросли за рахунок свіжого опаду листяних дерев, про що свідчить частка листя ( $\geq 30 \%$ ) у фракційному складі та потужність підгоризонту L -2.1 см (контроль).

Відібрані зразки підстилки у верхній частині стежки №1 та нижній - №2 показали, що запаси лісової підстилки на обох ділянках суттєво не відрізняються (1.35 та 1.30 кг $\mathrm{M}^{-2}$, відповідно), а їх результати знахо- дяться в межах статистичної похибки (табл.1). Через пошкодження, подрібнення та ущільнення, лісова підстилка на відносно рівній поверхні спресована, а іiї потужність, у порівнянні 3 контролем, зменшилась у 3 рази. По-тужність підгоризонту L становить 0.3-0.5 см. Цей підгоризонт сформо-ваний в основному свіжим, злегка пошкодженим листям бука. Підгоризонти F та Н окремо не діагностуються, а тому формують один підгоризонт потужністю до $1 \mathrm{~cm}$, який представлений напіврозкладеними (оторфованими) частинками листя та хвої.

Відносно неширока стежка $(0.75$ м-1.50 м) досліджуваного маршруту сприяє нагромадженню лісової підстилки вздовж узбіччя стежки. Таким чином, на узбіччях стежок даного маршруту формується досить потужна підстилка (4.5-4.8 cм), запаси якої сягають 2.19-2.26 кг· $\mathrm{M}^{-2}$, що в 1.03-1.06 разів більші ніж на контролі. На узбіччях стежок добре простежуються підгоризонти L, F та H (табл.1). Значною потужністю характеризується підгоризонт L ( $\geq 2$ 
см), сформований свіжим листям бука.

За результатами проведених досліджень на туристичному маршруті «Коростів-Парашка» встановлено, що запаси підстилки становлять 1.90 кг· $\mathbf{M}^{-2}$. Як на теплий період року (наприкінці літа - на початку осені) вона $є$ досить потужною (3.5 см). Її потужність в основному збільшилась за рахунок активної фракції, зокрема часток листя та хвої. Підгоризонт L становить 1 см, а підгоризонт F + H $1,5 \mathrm{~cm}$.

Запаси підстилки у нижній частині стежках №1 та верхній - №2 становлять 1.29-1.23 кг $\mathrm{M}^{-2}$ відповідно. Це свідчить про відносно менше рекреаційне навантаження $(\mathrm{p}<0.05)$ на даному маршруті в порівнянні 3 еколого-пізнавальним маршрутом «Сколе-Парашка». При дослідженні маршруту також було виявлено, що в нижній частині стежки (№1) запаси підстилки на 5 \% більші, ніж у їі верхній частині (№2). Подібна тенденція спостерігається i за показниками потужності підстилки, яка в основному сформована підгоризонтами F+H.
При досліджені туристичного маршруту «Коростів-Парашка» було виявлено, що на стежці, яка проходить впоперек схилу 3 крутизною $\geq 15^{\circ}$ i кутом нахилу поверхні до $5-9^{\circ}$, створюються певні особливості у нагромадженні лісової підстилки. Встановлено, що на узбіччях стежок формується «верхній валик» (узбіччя ліворуч від основної стежки) та «нижній валик» (узбіччя праворуч від основної стежки).

Основні результати щодо потужності лісової підстилки на всіх еколого-пізнавальних та туристичному маршрутах надані у рис. 2.

За нашими дослідженями виявлено, що різниця за показниками запасу лісової підстилки між «верхнім валиком» та «нижнім валиком» становить 1.4-1.6 рази (рис 2.). Потужність нижнього та верхнього валика в основному формується підгоризонтами L та F. Однак, підгоризонт F для нижнього валика $\epsilon$ дещо потужнішим, а формують його в основному напіврозкладені плоди та гілки. 


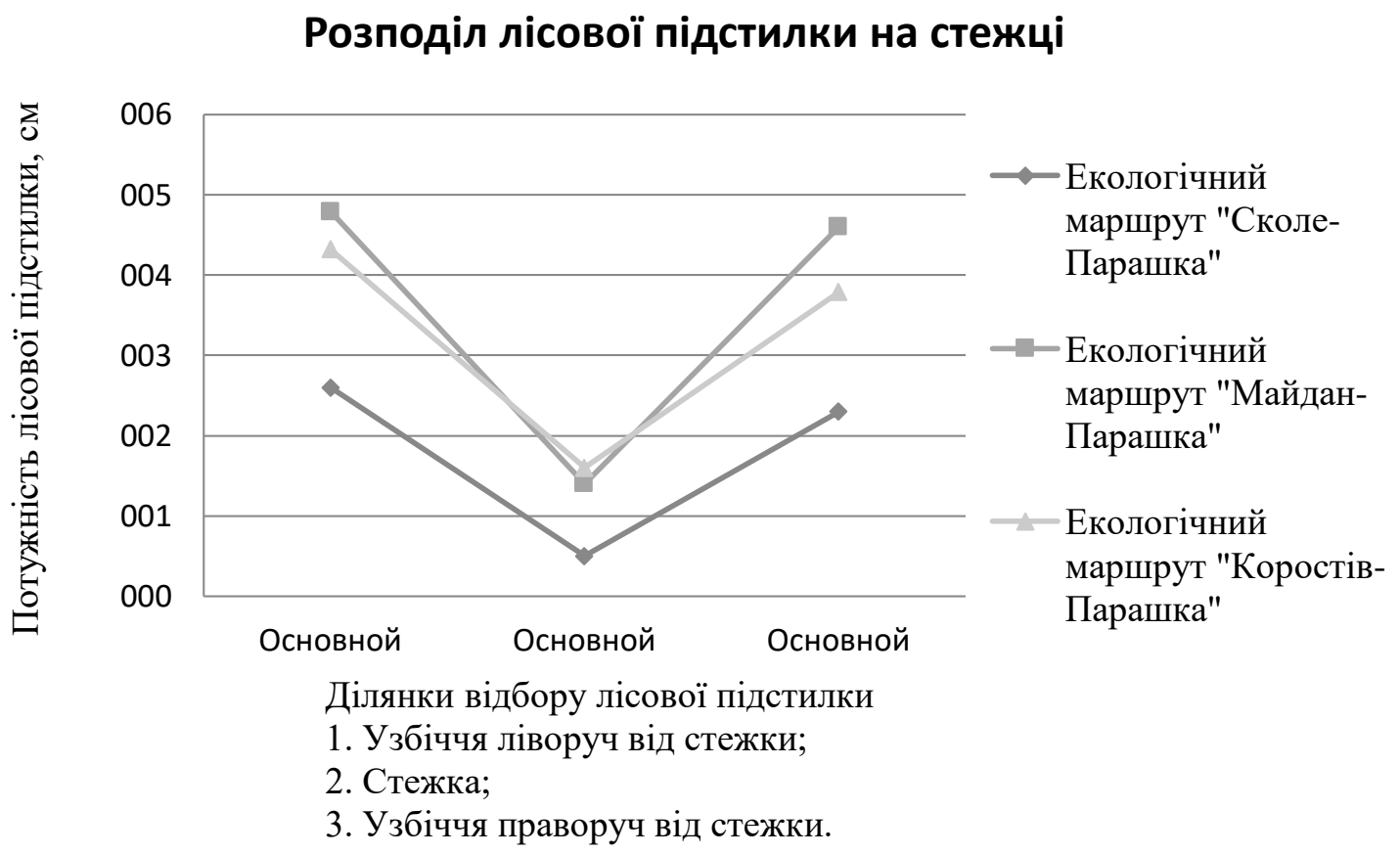

Puc. 2. Розподіл лісової підстилки на стежках екологічних маршрутів НПП Сколівські Бескиди (Східні Карпати, Україна).

Такий розподіл фракцій у лісовій підстилці можна пояснити механічним перенесенням крупніших частинок плодів, гілок та листя туристами-рекреантами із основної стежки до узбіччя, а саме до «нижнього валика». На відносно рівній поверхні стежки (екологопізнавальний маршрут «МаданПарашка) різниця за показниками запасу лісової підстилки між «нижнім валиком» та «верхнім валиком» $€$ не значною.

\section{ОБГОВОРЕННЯ}

Проведені дослідження на еколого-пізнавальних та туристичному маршрутах дозволили встановити певні закономірності нагромадження лісової підстилки на стежках:

Запаси та потужність лісової підстилки суттєво залежать від ширини стежки. Встановлено, що чим вужча стежка, тим більші показники запасу підстилки фіксу- ються на стежці та іï узбіччі i навпаки, чим стежка ширша, тим менше на ній та іiі узбіччі запасів лісової підстилки. На стежках шириною $\quad 1.85-2.20 \mathrm{~m}$ запаси підстилки зменшуються більше ніж наполовину в порівнянні 3 контролем. 3 крутизною схилу, сильно пошкоджена лісова підстилка змивається 3 «верхньої стежки» до «нижньої». 3 шириною стежки змінюються також і морфологічні особливості лісової підстилки. На стежках шириною 0.65-1.80 м можна виділити морфологічно підгоризонти $\mathrm{L}$ та $\mathrm{F}+\mathrm{H}$, тоді як на стежках шириною 1.85-2.20 м вони майже не діагностуються. На крутих схилах $\geq 15^{\circ}$ підгоризонт $\mathrm{F}+\mathrm{H}$ практично відсутній, однак у виположеній частині ділянки його потужність зростає, щонайменше у два рази. Схожі результати дослідження були встановлені Ю.М. Чорнобаєм в корінних лісових угрупованнях 
Українських Карпат, зокрема в ялицево-смерековій бучині запаси лісової підстилки на вирівняній ділянці схилу становили 1.1 та 2.3 $\kappa \Gamma^{\cdot} \mathrm{M}^{-2}$ в мікропониженнях. [9]. Найбільш помітні зміни спостерігаються на узбіччі стежок. В основному запаси підстилки зростають за рахунок свіжого опаду (L) та ферментативного (F) - підгоризонту, сформованого гілками та плодами.

За незначного рекреаційного навантаження (I-II стадія/категорія) $[10,11]$ лісова підстилка в основному подрібнюється, проте вкриває поверхню стежки, і тільки на крутих схилах $\left(>20^{\circ}\right)$ може бути фрагментарно відсутня. На більш вирівняній поверхні пошкоджена підстилка втоптується у верхній гумусово-акумулятивний горизонт, формуючи $\mathrm{F}+\mathrm{H}$ підгоризонт потужністю до $1 \mathrm{~cm}$.

Надходження свіжого опаду лісової підстилки суттєво впливає на показники запасів та потужності підстилки на стежках та їх узбіччях. Однак, під впливом витоптування все ж спостерігається тенденція до зменшення основних параметрів лісової підстилки.

На всіх стежках формуються так звані «валики», запаси яких залежать від крутизни схилу, ширини стежки та рекреаційного навантаження. Слід зазначити ще певні особливості нагромадження лісової підстилки на стежках, прокладених впоперек схилу. На таких ділянках формується «верхній валик» та «нижній валик», причому різниця в запасі підстилки між ними становить 1,4-1,6 рази. Схожу тенденцію нагромадження лісової підстилки в гірській місцевості (Чорногора, Українські Карпати) в межах стежок було відзначено О. Марфеніною із співавторами [7].

Зімкнутість деревного покриву у формуванні та нагромадженні лісової підстилки відіграє важливу роль. Виявлено, що менша зімкнутість деревного покриву також впливає на нагромадження лісової підстилки на стежках, в тому числі на їх узбіччі. На таких ділянках швидше відбуваються процеси трансформації органічної речовини, про що свідчать запаси лісової підстилки на узбіччі стежки на еколого-пізнавальному маршруті «Сколе-Парашка» у верхній iï частині (2a).

\section{ВИСНОВКИ}

На основі проведених досліджень встановлено, що на лісових еколого-пізнавальних і туристичному маршрутах (стежках) розподіл лісової підстилки спостерігається в межах основної стежки та iii узбіччя. Виявлено, що запаси та потужність лісової підстилки на стежках зменшується на 10-30 \% в порівнянні 3 контролем та суттєво залежать від інтенсивності рекреаційного навантаження. Внаслідок витоптування найбільше пошкоджується фракція листя, хвої та гілок. Їх частка в межах стежки зменшується, тоді як на узбіччях стежок, навпаки, збільшується, що зумовлено механічним перенесенням та змиванням дощовими водами. В результаті чого на всіх стежках формуються так звані «валики», запаси яких залежать від крутизни схилу, ширини стежки та рекреаційного навантаження. За незначного 
рекреаційного навантаження лісова підстилка на стежці подрібнюється, проте вкриває поверхню стежки, i тільки на крутих схилах $\left(>15^{\circ}\right)$ може бути фрагментарно відсутня. На більш рівній поверхні $\left(\leq 10^{\circ}\right)$ пошкоджена підстилка втоптується у верхній гумусово-акумулятивний горизонт, формуючи $\mathrm{F}+\mathrm{H}$ підгоризонт потужністю до $1 \mathrm{~cm}$. Нагромадження лісової підстилки на стежках, які проходять впоперек схилу 3 крутизною $\geq 15^{\circ}$ і кутом нахилу поверхні до 5-7 ${ }^{\circ}$ характеризуються певними особливостями. По-перше, у нижній частині стежки формується більш потужна лісова підстилка, ніж у пї верхній частині, приблизно на 5 \%. По-друге, по обидві сторони узбіччя стежки формуються «валики - нижній та верхній», а різниця у запасах підстилки між ними становить 1,41,6 рази. 3 посиленням рекреаційного навантаження запаси підстилки зменшуються більше ніж наполовину в порівнянні 3 контролем i становлять менше 1 кг' $\mathrm{M}^{-2}$.

\section{Список використаних джерел}

1. Bhantsova V.A.,Bhantsova V.N., Sokolov L.A. (1987) Vlyianye rekreatsyonnoho lesopolzovanyia na pochvu. Pryrodnыe aspektы rekreatsyonnoho yspolzovanyia lesa. Otvetstvennyi redaktor d.b.n. L. Rыsyn. M.:
Nauka. 70-95.

2. Holubets M.A., Polovnikov L.I. (1975) Zahalni zakonomirnosti nahromadzhennia fitomasy $\mathrm{v}$ smerekovykh lisakh. Biolohichna produktyvnist smerekovykh lisiv Karpat. K: Naukova dumka. 4-68.

3. Zapotochnyi M.M. (2015) Rekreatsiine lisokorystuvannia na pivnichno-skhidnomu mehaskhyli Ukrainskykh Karpat [avtoreferat. dysertatsii kand. s.-h. nauk]. Lviv: Natsionalnyi lisotekhnichnyi universytet Ukrainy. $19 \mathrm{~s}$.

4. Yvonyn V.M., Voskoboinykova Y.V. (2014) Vlyianye turyzma na protsessы эrozyy pochv v lesakh nyzkohoryi severo-zapadnoho Kavkaza. Nauchnыi zhurnal Rossyiskoho NYY problem melyoratsyy. №4 (16). 87-104.

5. Karpachevskyi L.O., Kyseleva N.K. (1968) O metodyke ucheta opada y lesnoi podstylky $\mathrm{v}$ smeshannыkh lesakh. Lesovedenye. №3. 73-79.

6. Marfenyna O.E., Zheveleva E.M., Zaryfova Z.A., Rozyna M.S., Makarova N.A., Ofytserova O.V. (1984) Vlyianye normyrovannыkh rekreatsyonnыkh nahruzok na svoistva burыkh lesnыkh pochv. Vestn. MHU. Ser. 17. Pochvovedenye. № 3. $52-58$.

7. Marfenyna O.E., Honcharova N.Y., Rozyna M.S. (1988) Posledstvyia rekreatsyonnoho vozdeistvyia na podstylku lesnыkh (elovыkh) byoheotsenozov. Эkolohyia. №2. 7-12.

8. Rыsyn L.P. Rыsyn S.L. (2008) Pryrodnыe y sotsyalnye aspektы rekreatsyonnoho yspolzovanyia lesov. Lesokhoziaistvennaia ynformatsyia. № 6-7. 37-52.

9. Chornobai Yu.M. (2000) Transformatsiia roslynnoho fitodetrytu v pryrodnykh ekosystemakh. Lviv: Vyd-vo Derzhavnoho pryrodoznavchoho muzeiu NAN Ukrainy. $352 \mathrm{~s}$.

10 Prendky R. (1999) Otsinka vplyvu pryrodnomu seredovyshchu natsionalnoho parku Beshchady $\mathrm{v}$ mezhakh pishykh turystychnykh marshrutiv u 1995-1999 rokakh - porivniannia rezultativ monitorynhu. Litopysy pryrody Beshchady. (8). 343-352

11. Prendky R. (2000) Zmina povitriano-vodnykh vlastyvostei gruntiv $\mathrm{v}$ mezhakh pishokhidnykh stezhok natsionalnoho park Beshchady. (9). 225- 235

\section{UDC 631.484}

\section{THE INFLUENCE OF RECREATION LOADING ON THE MORPHOLOGICAL SPECIFICS OF FOREST LITTER (NPP «SKOLIVSKI BESKYDY», UKRAINIAN CARPATHIANS)}

\section{Lenevych O.I.}

The article deals with the analysis of morphological aspects of the forest litter structure on ecological and tourist routes in the mountainous region. The study revealed that the changes in the basic parameters of the forest litter are caused by ground trampling. It was estimated that on trails between $0.5 \mathrm{~m}$ and $2 \mathrm{~m}$ wide, the stock of forest litter is 1.23 $1.5 \mathrm{~kg} / \mathrm{m}^{2}$, and its capacity is $1.3-1.6 \mathrm{~cm}$. With the supply of fresh foliage on the trails, the L, $F$ and $H$ sub-horizons can be identified there. On trails of 2 to $3 \mathrm{~m}$ wide, the stock of forest floor is $0.51-0.91 \mathrm{~kg} \cdot \mathrm{m}^{2}$, that is almost twice less than on narrower trails. The capacity of the litter on trails more than $2 \mathrm{~m}$ wide is 0.3-0.5 cm, of which 0.2-0.4 is the F+H sub- 
horizon. On slopes with $\geq 15^{\circ}$, the reserves and capacity of the forest litter in the lower part of the trail are about $10 \%$ greater than in its upper part.

Basically, the redistribution of forest litter is observed within a trail and its side. The stock of forest litter on the trail decreases due to the fact that the damaged litter is removed outside the trail. In the spring and summer, the forest litter is washed off by rain and melt water, forming the so-called "rollers" on its road (trail). The capacity and reserves of forest litter on the sidewalks are significantly dependent on the width and direction of the trail. The narrower the trail, the larger are the forest litter reserves and on the contary, the wider the trail, the smaller is the forest litter within the sidewalk. The capacity of the forest litter on the side of the trails of the studied routes ranges from $1.3 \mathrm{to} 4.8 \mathrm{~cm}$, and its reserves have increased to $1.44-2.26 \mathrm{~kg} \cdot \mathrm{m}^{2}$. A composition of tree species, tree layer compactness and terrain play an important role in the formation of forest litter as well.

The impact of recreation load on the soil cover was also evaluated. It was established that at the initial stages (of I-II categories) of recreation digression, the forest litter becomes compacted and crushed, forming a powerful $F+H$ subhorizon and covering the trail surface. As the recreation load increases (III stage/category) the stock of litter in sprucebeech-fir forest in the warm season is less than $1 \mathrm{~kg} / \mathrm{m}^{2}$.

Key words: forest litter, capacity and stock, ecological and tourist route, NPP "Skolivski Beskydy" Ukrainian Carpathians.

Своїм приємним обов’язком вважаю висловити щиру подяку Інституту екології Карпат НАН України за проведення наукових досліджень, а також науковим співробітникам за допомогу у проведені дослідженя, слушних зауваженнях та порадах, зокрема науковому керівнику к.б.н., с.н.с. О.Г. Марискевич та к.б.н., с.н.с. I.М. Шпаківській $\quad$ i к.б.н., B.I. Козловському.

Стаття надійшла 12. 09. 2019 р. Рекомендована до друку на засіданні редакційної колегї̈ після рецензуванн 